\title{
The Relationship Between Parkinson's Disease and Bone Density
}

\author{
Parkinson Hastalığı İle Kemik Yoğunluğunu İlişkisi \\ İsmet Melek ${ }^{1}$, Hava Özlem Dede ${ }^{1,{ }^{*}}$, Taşkın Duman $^{1}$, Esra Okuyucu ${ }^{1}$, Yusuf Tamam ${ }^{2}$ \\ ${ }^{1}$ Mustafa Kemal University Hospital Neurology Department, Hatay \\ ${ }^{2}$ Dicle University Hospital Neurology Department, Diyarbakir
}

\begin{abstract}
Objective: Patients with a diagnosis of Parkinson's disease face an increased risk of bone fracture, especially fracture of the head of the femur. This increased risk has been attributed to the postural instability characteristic of the disease, to neurological damage or to a reduction in bone mineral density. Because of the increased frequency of falling and its complications, the link between Parkinson's disease and osteoporosis demands attention. For this reason, we thought it of value to investigate the relationship between Parkinson's disease and the incidence of osteoporosis in the Turkish population.
\end{abstract}

Materials and Methods: We compared a group of 65 idiopathic Parkinson's patients with a control group of 30 individuals, who were matched for age and sex, and who had no known systemic diseases, for bone mineral density. Individuals with electrolyte and metabolic diseases which might affect bone metabolism were excluded from the study. The stage of Parkinson's disease was determined according to UPDRS and Hoehn and Yahr scores.

Results: Results of the study showed a significant reduction in bone mineral density in Parkinson's patients compared to the control group; also, as the stage of the disease advanced according to the Hoehn and Yahr score, and as immobility increased, so bone mineral density decreased (p:0.037).

Conclusion: In the light of these results, we emphasize that osteoporosis and its possible complications should be taken into account when planning primary and secondary care treatments for Parkinson's patients.

Key Words: Parkinson's Disease, osteoporosis, bone mineral density, motor complications

\section{Introduction}

Parkinson's Disease is a progressively degenerative disease in which the patient needs special care, bodily movements gradually slow down, and life becomes impossible without support, and one in which even neurology provides little hope. The prevalence of the disease is $0.6 \%$ in the $60-65$ year age group, and $3 \%$ in those over 80 years of age

\section{ÖZET}

Amaç: Parkinson hastalı̆̆ı tanısıyla takipli hastalar artmıș fraktur; özellikle femur baş1 frakturu riskiyle karş1 karşıyadır. Bu risk artışının hastalığa özgü postural instabilite, nörolojik hasar ya da kemik mineral yoğunluğundaki azalmaya bağlanabileceği öne sürülmüştür. Parkinson hastalığında düşme sıklığ1 ve komplikasyonlarının artışı nedeniyle Parkinson hastalığı ve osteoporoz ilişkisi önemini korumaktadır. Bu nedenle Türk toplumundaki Parkinson hastalı̆̆ıyla osteoporoz varlığ arasındaki ilişki incelemeye değer bulunmuştur.

Gereç ve Yöntem: 65 idiyopatik parkinson hastasının dahil olduğu hasta grubu ile cinsiyet ve yaş aralığ uyumlu, bilinen sistemik hastalığ1 olmayan 30 bireyi kontrol grubu olarak kabul ederek kemik mineral yoğunluklarını karşılaştırdık. Kemik metabolizmasına etkisi olabilecek elektrolit ve metabolik hastalığa sahip bireyler çalışma dişı tutulmuştur. Parkinson hastalığ1 UPDRS ve Hoehn \&Yahr skalalarına göre evrelendirilerek incelenmiştir.

Bulgular: Çalışmanın sonucunda Parkinson hastaları grubunda anlamlı olarak kemik mineral yoğunluklarında kontrol grubuna göre azalma; ayrıca hastalık evresi Hoehn\&Yahr skalasına göre arttıkça; hastaların immobilitesi arttıkça, kemik mineral yoğunluğunda azalma saptand 1 (p:0.037).

Sonuç: Bu sonuçlar 1şığında Parkinson hastalığı tanısıyla takipli bireylerde primer ve sekonder koruma tedavilerini planlarken osteoporoz ve olası komplikasyonların göz önünde bulundurulması gerektiğini vurgulamaktayız.

Anahtar Kelimeler: Parkinson hastalığı, osteoporoz, kemik mineral yoğunluğu, motor komplikasyonlar

(1). Falls start to be seen frequently even in Parkinson's patients who only have difficulty in moving their heads, in addition to their autonomic dysfunction. Motor blocks and delays in the initiation and termination of movements often result in loss of balance. One of the problems involved in frequent falls in patients in the middle-aged and elderly age groups is the increased risk of broken bones (2). 
The relationship between Parkinson's disease and osteopenia, which increases the risk of fracture, has been the subject of research (3-6).

The changes which increase the risk of broken bones are related to bone mineral density and trauma (7). Osteoporosis is a disease in which the bones become spongier, and gradually become less resilient and more fragile. Among the factors which increase the risk of osteoporosis are insufficient calcium in the diet, vitamin $D$ deficiency, insufficient exercise, factors which cause hyperparathyroidism, the use of steroids, and advanced age. The fact that idiopathic parkinsonism is frequently seen in people of advanced age means that the risk of osteopenia is increased for such reasons as lack of exercise (8, 9). The frequency of falling, which is a characteristic of the disease, also increases the observed risk of fractures in Parkinson's patients $(10,11)$. The fractures occurring in Parkinson's patients who are dependent on the care of those around them directly affects their health and morbidity, and increases complications. Many studies, which have been conducted, have shown that Parkinson's disease is a direct cause of osteopenia, and that the incidence of osteopenia in Parkinson's patients increases $(4,12,13)$.

The aim of the this study was to show the relationship between bone density and the course of the disease in Parkinson's patients in our region, and thus to draw attention to the importance of the risk of fracture and its contribution to morbidity and mortality.

\section{Materials and Methods}

Approval was obtained from the Ethics Committee for this work, and written consent was obtained from all patients who took part. Patients included in the study were 65 outpatients with idiopathic Parkinson's disease who attended the movement disorders clinic of the M.K. University Medical Faculty Hospital's Neurology Department between April 2010 and January 2011. The diagnosis of parkinsonism was carried out in accordance with the diagnostic criteria of the UK Brain Bank (14). Parkinson's disease is characterised by rest tremor, bradykinesia, rigidity and postural instability. The key symptom of the UK Brain Bank criteria is bradykinesia. According to these criteria, bradykinesia, and along with it the presence of at least one of the symptoms of rigidity, rest tremor and postural instability, is accepted as sufficient for a diagnosis of Parkinson's disease. The diagnosis of Parkinson's disease was given to the group of patients included in the study in the movement disorders clinic in accordance with these criteria. The patients had been monitored by periodic checkups in the clinic approximately every two months. Patients were excluded from the study who had findings which were considered to be of diseases other than Parkinson's: the existence of marked postural instability within three years of the appearance of symptoms, observation of freezing in the first three years, hallucinations unrelated to medication in the first three years, dementia prior to motor symptoms or in the first two years, supranuclear visual paralysis or slowness of vertical eye movements, slow symptomatic dystonomy unrelated to medication, and documentation of anything which could be related to a known cause of parkinsonism or to the patient's symptoms, such as the use of neuroleptics within the previous six months.

Those with a previous diagnosis or treatment for osteopenia, those with parathyroid disease, those with bone-related diseases, those who had suffered a fracture related to osteoporosis, cases of secondary parkinsonism, and those with a history of seizure were excluded from the study. Patients who were accepted but whose peripheric venous blood level of 25 hydroxyvitamin $\mathrm{D}$ was measured at below the normal limit $(10 \mathrm{pg} / \mathrm{mL})$ and were thus considered deficient in vitamin $\mathrm{D}$ were excluded. Before being accepted for the study, all patients were tested for levels of calcium, magnesium, phosphorus and alkaline phosphatase, which are important for bone metabolism, and those with measurements outside normal laboratory standards were excluded.

The sixty-five idiopathic Parkinson's patients were matched for sex and age with 30 patients in a control group. Members of the control group were chosen from among patients attending the neurology outpatients' clinic who did not have diseases known to affect bone metabolism, taking account of age group and sex.

The course of the Parkinson's disease was measured by the UPDRS (Unified Parkinson's Disease Rating Scale) and the HY (Hoehn and Yahr) scale. Measurements were made by a neurologist in the movement diseases clinic. HY indicates the stages in the progression of the disease from mild symptoms on one side to the final stage of immobility (15). Points are given from one to five. UPDRS is a scale, which evaluates the clinical severity of the disease with 41 questions on behavioural and mental state, activities of daily life, motor examination, 
treatment complications, and other complications. As the severity of the disease increases, the HY and UPDRS scores also increase. The HY scale was used to measure the severity and progression of the disease, while the patient's capacity for movement and daily life activities were evaluated using UPDRS. Bone mineral density of all participants, both patients and controls, was measured by DEXA (Dual Energy X-ray Absorbtiometry). A T score of between -1.5 and 2 measured at the anteroposterior lumbar spine and the head of the left femur was taken to indicate osteopenia, and a score of less than -2 to indicate osteoporosis. In addition, bone mineral density was compared between the patient and control groups. Statistical analysis was performed using SPSS 13. Relationship between groups and variables was examined by the chi-square test. In evaluation of mean and standard deviation, $\mathrm{p}<0.05$ was accepted as significant.

\section{Results}

Demographic characteristics of the patient group in the study are shown in Table 1 . Women formed $36.9 \%$ of the group, and men $63.1 \%$. Duration of Parkinson's disease was less than two years in $10.8 \%$ of the group, $2-5$ years in $50.8 \%$, 5 10 years in $27.7 \%$, and over ten years in $10.8 \%$.

As the severity of Parkinson's disease increased according to the Hoehn and Yahr classification (Table 2), there was a significant decrease in the $\mathrm{T}$ score of the head of the left femur ( $p=0.037)$. No significant correlation was found between UPDRS and a low $\mathrm{T}$ score $(\mathrm{p}=0.087)$. A negative correlation was found between the Hoehn and

Table 1. Descriptive statistics of the Patient and Control Groups in the Study

\begin{tabular}{lll}
\hline & Patient & Control \\
\hline Number & 65 & 30 \\
\hline Age & $67.49 \pm 1.15$ & $66.53 \pm 2.23$ \\
\hline SEX(Male/Female) & $24 / 41$ & $10 / 20$ \\
\hline Bone Density & & \\
\hline T score (SPINE) & $-1.63 \pm 1.2$ & $-1.01 \pm 0.5$ \\
\hline T score (left femur) & $-1.71 \pm 0.9$ & $-1.21 \pm 0.5$ \\
\hline Spine BMD $\left(\mathrm{g} / \mathrm{cm}^{2}\right)$ & $0.97 \pm 0.1$ & $1.05 \pm 0.2$ \\
\hline Head of Left Femur & $0.82 \pm 0.1$ & $0.96 \pm 0.3$ \\
BMD $\left(\mathrm{g} / \mathrm{cm}^{2}\right)$ & & \\
\hline
\end{tabular}

The mean UPDRS value of the patients in the study was 36.73 (min. 9, $\max .94$ ).
Yahr score and the left femur BMD value $(p=0.041)$. There was a correlation between the H\&Y and the UPDRS scores $(p=0.00)$. All these results indicate that as the severity of Parkinson's disease and restriction of movement progress and independence in the activities of daily life decreases, bone mineral density is reduced. This increases osteopenia and the risk of fracture.

Drugs used in the previous year in connection with Parkinson's disease by patients in the study were as follows: 27 patients $(41.5 \%)$ used Levodopa + benserazid, $11(16.5 \%)$ used levodopa + karbidopa + entakapon, eight (12.3\%) used pramipeksol, and one (1.5\%) used ropinirol (Table 3).

Table 2. The Relationship between H\&Y (Hoehn $\&$ Yahr) Scores and Bone Density Measurements

\begin{tabular}{llrr}
\hline H\&Y & & Left femur & AP spine \\
\hline 1 & Mean & -1.4900 & -1.6300 \\
& $\mathrm{n}$ & 20 & 20 \\
& Std. Deviation & 1.21174 & 1.11596 \\
\hline 2 & Mean & -1.6862 & -1.4552 \\
& $\mathrm{n}$ & 29 & 29 \\
& Std. Deviation & 0.77401 & 1.22083 \\
\hline 3 & Mean & -1.8364 & -1.7455 \\
& $\mathrm{n}$ & 11 & 11 \\
& Std.Deviation & 0.76062 & 1.22667 \\
\hline 4 & Mean & -2.5000 & -2.4400 \\
& $\mathrm{n}$ & 5 & 5 \\
& Std. Deviation & 0.66708 & 1.36492 \\
\hline Total & Mean & -1.7138 & -1.6338 \\
& $\mathrm{n}$ & 65 & 65 \\
& Std. deviation & 0.93973 & 1.20030 \\
\hline
\end{tabular}

$\mathrm{n}$ : number of observation

Table 3. Drugs Used by the Patient Group

\begin{tabular}{lll}
\hline Drug & $\mathrm{n}$ & $\%$ \\
\hline Levodopa + Benseraside & 27 & 41.5 \\
\hline Levodopa + carbidopa + entacapone & 11 & 16.9 \\
\hline pramipeksol & 8 & 12.3 \\
\hline ropinirol & 1 & 1.5 \\
\hline $\mathrm{M}+\operatorname{Pr}$ & 10 & 15.4 \\
\hline $\mathrm{M}+\mathrm{Ro}$ & 2 & 3.1 \\
\hline $\mathrm{S}+\operatorname{Pr}$ & 2 & 3.1 \\
\hline S+Ro & 2 & 3.1 \\
\hline Azilect & 2 & 3.1 \\
\hline M:Levodopa+Benseraside, n:number, Pr: pramipeksol, \\
Ro:ropinirol S:Levodopa+carbidopa +entacapone, $)$
\end{tabular}




\section{Discussion}

Parkinson's disease (PD) is a degenerative process of the basal ganglia, especially the substantia nigra, which also affects the other pigmented neurons of the brain stem, and this occurs in $80 \%$ of all cases of parkinsonism (16,17). Its main clinical signs are rest tremor, bradykinesia, rigidity and postural reflex disorder (18). Its prevalence in the total world population is around $0.6 \% \quad(16,17)$. Prevalence in Turkey has been shown to be 111/100000 (19).

In the advanced stages of idiopathic Parkinson's disease (IPD), problems of balance and standing upright are added to the negative symptoms such as bradykinesia, postural fixation, locomotion problems, phonation-articulation problems and akinesia. Along with degeneration of the substantia nigra, possible hyperactive pallidal inhibition or hypofunction of the pedunculopontine nucleus (PPN) $(20,21)$ and neurodegeneration (22) may be the cause of these negative symptoms (23). In this regard, balance problems and postural instability in IPD do not show as positive a response to dopaminergic treatment as bradykinesia does.

The main centres of the mechanisms for posture are located in the brain stem. The pontomedullary reticular formation is an important structure in the control of posture and balance. Voluntary and involuntary posture control, proprioception and sight are coordinated by the labyrinthine function and communication afferents. The cerebral cortex, the cerebellar nuclei, the basal ganglia, and the pontomedullary, reticuloreticular and reticulospinal neurons play an important role in posture control. It has been shown to be a projection from the substantia nigra to the bulbopontine reticular formation and especially to the PPN (24). Posture control is achieved by pathways coming from supraspinal structures, and the ventromedial system consisting of vestibulospinal, interstitiospinal and tectospinal pathways (25).

It has been suggested that the appearance of posture control and balance problems in advanced IPD patients may be related to common anatomical structures, especially hypofunction of the PPN and neurodegeneration (20).

Falls relating to loss of balance are an important risk factor for fractures in patients of advanced age $(26,27)$. A study, which examined the frequency of falling in 100 Parkinson's patients found that $38 \%$ had had, falls, and that $13 \%$ fell more than once a week (28). Many studies examining the risk of fractures in Parkinson's patients have shown that this group of patients suffer frequent fractures of the femur because of frequent falls (29). It has been suggested that along with the increased frequency of falls, another factor, which increases the risk of fracture, may be a reduction in bone mineral density (30). Results obtained from studies on this topic have shown lower bone mineral density in Parkinson's patients in parallel with the advancement their disease in comparison with others in the same age group (31). In our study also, as the stage of the disease advanced according to the Hoehn \& Yahr score, so bone mineral density and the DEXA T score decreased. A reduction in physical activity can be seen as one of the important parameters in this scenario (32).

The pathophysiology of greater risk of fractures and increased frequency of osteoporosis in Parkinson's patients is affected by immobilisation, endocrine changes, inadequate nutrition, and iatrogenic factors $(13,33)$. Among endocrine changes in which the Parkinson's group showed differences from the control group were in the metabolism of growth hormone, prolactin, carboxylated osteocalcin, vitamin $\mathrm{K}$ and vitamin $\mathrm{D}$ (34). Some studies have found vitamin D levels to be low in Parkinson's patients compared to control groups, and it has been suggested that vitamin $\mathrm{D}$ may affect not only bone metabolism but also the nervous system. Indeed, vitamin $\mathrm{D}$ deficiency by itself can be a cause of osteoporosis. In the present study, we excluded the vitamin $\mathrm{D}$ deficiency seen in Parkinson's patients because it is a cause of osteoporosis. When evaluating the findings of osteopenia increasing with the frequency of Parkinson's disease, we included in the study Parkinson's patients whose vitamin D levels were within normal limits.

It has been suggested that the multi-drug treatment preferred for parkinsonism may carry a risk of osteoporosis (35). In our study, we did not detect any link between the drugs used and bone mineral density and DEXA scores. This may be because the number of patients in the study and the variations in combinations of drugs were insufficient to evaluate the effect of the drugs used.

In a six-year prospective multi-variable study by Schneider, it was emphasised that low bodyweight in Parkinson's patients also increased osteoporosis and the risk of fractures (36). It has been especially emphasised that osteoporosis, 
which is frequently seen in association with Parkinson's disease, has generally been left out of descriptions of the disease (37). Approaches to decreasing the risk of fractures in Parkinson's patients can be ranked as follows: to examine osteopenia in the clinical examination, to arrange effective treatment for osteoporosis, to reduce the risk of falls with a fall prevention programme, and to correct nutrition $(13,38)$.

Finally, data obtained in our study endorses the idea that the incidence of osteoporosis increases as Parkinson's disease advances. Falling and the increase in the incidence of osteoporosis in Parkinson's patients increase the risk of fracture. Complications such as fractures encountered in Parkinson's patients increase mortality and morbidity. Considering the increased incidence of osteoporosis in Parkinson's patients, we are of the opinion that evaluation of the patient in this regard will contribute to the treatment of Parkinson's disease by reducing the risk of fractures and complications.

\section{References}

1. Song IU, Kim JS, Lee SB, Ryu SY, An JY, Jeong DS, et al. The relationship between low bone mineral density and Parkinson's disease in a Korean population. J Clin Neurosci 2009; 16(6): 807-809.

2. Consensus development conference: prophylaxis and treatment of osteoporosis. Am J Med 1991; 90(1): 107-110.

3. Vaserman N. Parkinson's disease and osteoporosis. Joint Bone Spine 2005; 72(6): 484488.

4. Fink HA, Kuskowski MA, Orwoll ES, Cauley JA, Ensrud KE; Osteoporotic Fractures in Men (MrOS) Study Group. Association between Parkinson's disease and low bone density and falls in older men: the osteoporotic fractures in men study. J Am Geriatr Soc 2005; 53(9): 15591564.

5. Sato Y, Kaji M, Tsuru T, Oizumi K. Risk factors for hip fracture among elderly patients with Parkinson's disease. J Neurol Sci 2001; 182(2): 89-93.

6. Dobson R, Yarnall A, Noyce AJ, Giovannoni G. Bone health in chronic neurological diseases: a focus on multiple sclerosis and parkinsonian syndromes. Pract Neurol 2013; 13(2): 70-79.

7. Dargent-Molina P, Favier F, Grandjean H, Baudoin C, Schott AM, Hausherr E, et al. Fallrelated factors and risk of hip fracture: the EPIDOS prospective study. Lancet 1996; 348(9021): 145-149.
8. Lorefält B, Toss G, Granérus AK. Bone mass in elderly patients with Parkinson's disease. Acta Neurol Scand 2007; 116(4): 248-254.

9. Earhart GM, Falvo MJ. Parkinson disease and exercise. Compr Physiol 2013; 3(2): 833-848.

10. Stalenhoef PA, Diederiks JP, Knottnerus JA, Kester AD, Crebolder HF. A risk model for the prediction of recurrent falls in communitydwelling elderly: a prospective cohort study. J Clin Epidemiol 2002; 55(11): 1088-1094.

11. Van den Bos F, Speelman AD, Samson M, Munneke M, Bloem BR, Verhaar HJ. Parkinson's disease and osteoporosis. Age Ageing 2013; 42(2): 156-162.

12. Johnell O, Melton LJ 3rd, Atkinson EJ, O'Fallon WM, Kurland LT. Fracture risk in patients with parkinsonism: a population-based study in Olmsted County, Minnesota. Age Ageing 1992; 21(1): 32-38.

13. Invernizzi M, Carda S, Viscontini GS, Cisari C. Osteoporosis in Parkinson's disease. Parkinsonism Relat Disord 2009; 15(5): 339346.

14. Fahn S, Elton RL. Unified Parkinson's disease rating scale. In: Fahn S, Marsden D, Calne D, Goldstein M, editors. Recent Developments in Parkinson's Disease. New York: Macmillan Health Care Information; 2000: 153-163.

15. Hoehn MM, Yahr MD. Parkinsonism: onset, progression and mortality. Neurology 1967; 17(5): 427-442.

16. Adams RD, Victor M, Ropper AH. Principles of Neurology. 6 th ed. New York, NY: McGrawHill; 1997: 1067-1078.

17. Maraganore DM. Epydemiology and genetics Parkinson's disease. In:Wartts RL, Koller WC, eds. Mov Disord : Neurologic Principles and Practice. New York, NY: McGraw-Hill; 1997: 153-160.

18. Maraganore DM. Epydemiology and genetics Parkinson's disease. In:Wartts RL, Koller WC, eds. Mov Disord : Neurologic Principles and Practice. New York, NY: McGraw-Hill; 1997 : 153-160.

19. Torun Ş, Uysal M, Gücüyener D, Özdemir G. Parkinson's disease in Eskişehir,Turkey. Eur J Neurol 1995; 2: 44-45.

20. Crossman AR, Clarke CE, Boyce S, Robertson RG, Sambrook MA. MPTP-induced parkinsonism in the monkey: neurochemical pathology, complications of treatment and pathophysiological mechanisms. Can J Neurol Sci 1987; 14(3 Suppl): 428-435.

21. Crossman AR. A hypothesis on the pathophysiological mechanisms that underlie levodopa- or dopamine agonist-induced dyskinesia in Parkinson's disease: implications for future strategies in treatment. Mov Disord 1990; 5(2): 100-108. 
22. Zweig RM, Jankel WR, Hedreen JC, Mayeux R, Price DL. The pedunculopontine nucleus in Parkinson's disease. Ann Neurol 1989; 26(1): 41-46.

23. Lee MS, Rinne JO, Marsden CD. The pedunculopontine nucleus: its role in the genesis of movement disorders. Yonsei Med J 2000; 41(2): 167-184.

24. Rinvik E, Grofová I, Ottersen OP. Demonstration of nigrotectal and nigroreticular projections in the cat by axonal transport of proteins. Brain Res 1976; 112(2): 388-394.

25. Lee MS, Marsden CD. Drop attacks. Adv Neurol 1995; 67: 41-52.

26. Stalenhoef PA, Diederiks JP, Knottnerus JA, Kester AD, Crebolder HF. A risk model for the prediction of recurrent falls in communitydwelling elderly: a prospective cohort study. J Clin Epidemiol 2002; 55(11): 1088-1094.

27. Dargent-Molina P, Favier F, Grandjean H, Baudoin C, Schott AM, Hausherr E, et al. Fallrelated factors and risk of hip fracture: the EPIDOS prospective study. Lancet 1996; 348(9021): 145-149.

28. Koller WC, Glatt S, Vetere-Overfield B, Hassanein R. Falls and Parkinson's disease. Clin Neuropharmacol 1989; 12(2): 98-105.

29. Invernizzi M, Carda S, Viscontini GS, Cisari C. Osteoporosis in Parkinson's disease. Parkinsonism Relat Disord 2009; 15(5): 339346.

30. Fink HA, Kuskowski MA, Taylor BC, Schousboe JT, Orwoll ES, Ensrud KE;

31. Osteoporotic Fractures in Men (MrOS) Study Group. Association of Parkinson's disease with accelerated bone loss, fractures and mortality in older men: the Osteoporotic Fractures in Men (MrOS) study. Osteoporos Int 2008; 19(9): 1277-1282.

32. Bezza A, Ouzzif Z, Naji H, Achemlal L, Mounach A, Nouijai M, et al. Prevalence and risk factors of osteoporosis in patients with Parkinson's disease. Rheumatol Int 2008; 28(12): 1205-1209.

33. Taggart H, Crawford V. Reduced bone density of the hip in elderly patients with Parkinson's disease. Age Ageing 1995; 24(4): 326-328.

34. van den Bos F, Speelman AD, van Nimwegen M, van der Schouw YT, Backx FJ, Bloem BR, et al. Bone mineral density and vitamin $\mathrm{D}$ status in Parkinson's disease patients. J Neurol 2013; 260(3): 754-760.

35. Patel MS, Elefteriou F. The new field of neuroskeletal biology. Calcif Tissue Int 2007; 80(5): 337-347.

36. Vestergaard P, Rejnmark L, Mosekilde L. Fracture risk associated with parkinsonism and anti-Parkinson drugs. Calcif Tissue Int 2007; 81(3): 153-161.

37. Schneider JL, Fink HA, Ewing SK, Ensrud KE, Cummings SR; Study of Osteoporotic Fractures (SOF) Research Group. The association of Parkinson's disease with bone mineral density and fracture in older women. Osteoporos Int 2008; 19(7): 1093-1097.

38. Zhao Y, Shen L, Ji HF. Osteoporosis risk and bone mineral density levels in patients with Parkinson's disease: a meta-analysis. Bone 2013; 52(1): 498-505. 